\section{Meningitis and septicaemia due to haemophilus influenzae type $b$ in pregnancy}

Meningitis caused by Haemophilus influenzae is uncommon in adults. We report a case of meningitis and septicaemia caused by $H$ influenzae type $b$ in a pregnant woman.

\section{Case report}

A 22-year-old woman with a history of recurrent otitis media in childhood was admitted to hospital at 35 weeks of gestation with an upper respiratory tract infection of four weeks' duration. The day before admission she had had a fever of $38.5^{\circ} \mathrm{C}$, headache, and nausea. A few hours before admission her condition had deteriorated and she had lost consciousness.

Cerebrospinal fluid was cloudy and contained leucocytes $16 \cdot 1 \times 10^{9} / 1$ (16 $100 / \mathrm{mm}^{3} ; 93 \%$ polymorphonuclear cells), protein $8.0 \mathrm{~g} / \mathrm{l}$, and glucose $0.4 \mathrm{mmol} / 1(7.2 \mathrm{mg} / 100 \mathrm{ml})$. Cerebrospinal fluid and six blood cultures grew $H$ influenzae type $\mathrm{b}$, sensitive to benzyl penicillin, ampicillin and chloramphenicol. Chest $x$-ray picture was normal but sinus radiography showed left-sided maxillary sinusitis. Treatment consisted of intravenous ampicillin $16 \mathrm{~g}$ daily for eight days. The course was uneventful except for premature uterine contractions, which were stopped with terbutaline intravenously. Three weeks later she gave birth to a boy weighing $3280 \mathrm{~g}$. His development corresponded to 39 weeks of gestation. The Apgar score was 10 after one and five minutes. The placenta was normal and yielded no bacterial growth. One month later mother and child were well.

The patient's serum immunoglobulin concentrations on day 2 after admission were normal except for an $\mathrm{IgG}$ value of $4.9 \mathrm{~g} / 1$ (3 standard deviations below normal); on day 9 the value was $8.9 \mathrm{~g} / \mathrm{l}$. Serum $\operatorname{IgG}, \operatorname{IgM}$, and IgA antibodies specific to $H$ influenzae capsular polysaccharide type $b$ detected with the enzyme-linked immunosorbent assay ${ }^{1}$ and bactericidal ${ }^{2}$ antibodies against the strain isolated from the patient were found one day after admission. Much higher antibody titres were noted in serum samples obtained on days 33 and 58 after admission (figure). At delivery the same titres of specific anticapsular IgG and bactericidal antibodies were detected in sera from the mother and umbilical cord, while no specific IgM antibodies were detected in cord serum. IgA antibodies specific to capsular polysaccharide type $b$ were detected in breast-milk with the enzyme-linked immunosorbent assay on days 1 and 5 after parturition. These antibodies were probably of the secretory type as similar titres were obtained with anti-IgA and antisecretory component antisera (day 1 : serum IgA 2048 and secretory IgA 1024; day 5: serum IgA 64 and secretory IgA 64). Specific IgM antibodies in a titre of 64 were detected in the first breast-milk sample.

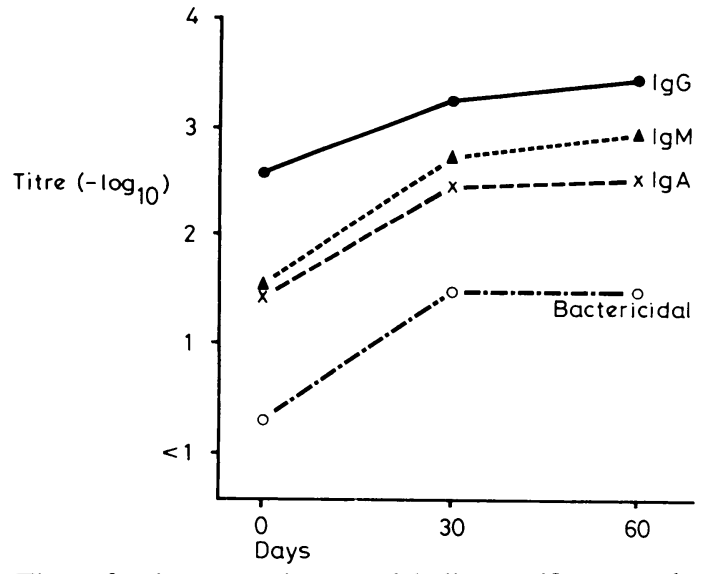

Titres of various serum immunoglobulins specific to capsular polysaccharide type $b$ and bactericidal antibodies against isolated strain of $H$ influenzae type b. Serum samples taken 1 , 33, and 58 days after admission.

\section{Comment}

Meningitis due to $H$ influenzae type $\mathrm{b}$ is primarily a disease of early childhood and is rarely encountered in adults. This is partly explained by the lack of bactericidal antibodies in young children and the acquisition of such antibodies in older children and adults. ${ }^{3}$ The antibody value that is protective against $H$ influenzae type $b$ disease has not been clearly defined, however. ${ }^{3}$

In our patient maxillary sinusitis was the most probable source of the infection. Initially she also showed a low total serum IgG concentration. Neutrophil chemotaxis, ${ }^{4}$ the ability to reduce nitroblue tetrazolium, ${ }^{4}$ and cell-mediated immune functions ${ }^{5}$ are depressed in pregnancy. Thus suppression of the maternal immune system might have contributed to the severe infection. Capsular polysaccharide type $b$ (unpublished observations) and bactericidal ${ }^{2}$ antibodies were present in titres corresponding to those of a healthy adult population, which suggests previous exposure to $H$ influenzae type $\mathrm{b}$ or other bacteria possessing cross-reacting antigens. ${ }^{3}$ Rising antibody titres indicate a normal immune response.

Placental transfer of specific IgG antibodies may give an important contribution to the infant's defence against $H$ influenzae type b infection. It is not known whether the high amount of specific secretory IgA found in colostrum will protect the newborn breast-fed against infection caused by $H$ influenzae type b locally in the respiratory tract.

${ }^{1}$ Dahlberg T, Branefors P. Enzyme-linked immunosorbent assay for titration of Haemophilus influenzae capsular and 0 antigen antibodies. $\mathcal{F} \mathrm{Clin}$ Microbiol 1980;12:185-92.

2 Branefors P, Dahlberg T. Serum bactericidal effect on capsulated and non-capsulated Haemophilus influenzae. Acta Pathol Microbiol Scand [C] $1980 ; 88: 47-56$.

${ }^{3}$ Norden CW. Haemophilus influenzae infections in adults. Med Clin North Am 1978;62:1037-46.

4 Björksten B, Söderström T, Damber M-G, von Schoultz B, Stigbrand T Polymorphonuclear leucocyte function during pregnancy. Scand $\mathcal{F}$ Immunol 1978;8:257-62.

5 Purtilo DT, Hallgren HM, Yunis EJ. Depressed maternal lymphocyte response to phytohaemagglutinin in human pregnancy. Lancet 1972 ; : 769-71.

(Accepted 12 December 1980)

Department of Infectious Diseases, University of Gothenburg,

East Hospital, S-416 85 Gothenburg, Sweden

T SANDBERG, $M D$, physician

Institute of Medical Microbiology, University of Gothenburg, Gothenburg, Sweden

T DAFILBERG, MS, research assistant

\title{
Effect of dobutamine on insulin requirement in diabetic ketoacidosis
}

Certain beta-adrenergic agonists-for example, isoprenaline, dopamine, and salbutamol-interfere with glucose tolerance in diabetes, resulting in hyperglycaemia and in some cases ketoacidosis. ${ }^{123} \mathrm{We}$ report a case in which dobutamine, a synthetic inotropic agent structurally related to dopamine, appreciably increased the insulin requirement of a diabetic in ketoacidosis.

\section{Case report}

A 45-year-old insulin-dependent diabetic woman presented with severe ketoacidosis. She was comatose, dehydrated, and ketotic with a heart rate of $100 / \mathrm{min}$ and blood pressure of $90 / 40 \mathrm{~mm} \mathrm{Hg}$. There was no clinical evidence of infection. Initial investigations showed a blood glucose concentration of $80 \mathrm{mmol} / \mathrm{l}(1441 \mathrm{mg} / 100 \mathrm{ml})$, bicarbonate $2 \mathrm{mmol}(\mathrm{mEq}) / \mathrm{l}$, hydrogen ion $180 \mathrm{nmol} / 1(18 \mathrm{ng} / 100 \mathrm{ml})$, haemoglobin $10 \cdot 2 \mathrm{~g} / \mathrm{dl}$, and white cell count of $18.5 \times 10^{9} / 1$, and normal chest $x$-ray appearances. Treatment consisted of an intravenous infusion of 5 units of neutral insulin (Actrapid MC) hourly and fluid replacement. Seven litres of isotonic saline were given over the first 24 hours, together with potassium replacement as indicated by plasma potassium estimation (approximately $20 \mathrm{mmol} / 1(\mathrm{mEq}) / 1$ hour). She responded well, becoming fully orientated within 24 hours. She was clinically 